Moore, T. \& Wang, Y. L. (1943). Biochem. F. 37, i.

Oliveira, D. de (1946). O Hospital, Rio de Faneiro, 29, 573.

Opie, E. L. (1899). F. exp. Med. 4, 279.

Pappenheimer, A. M. \& Schogoleff, C. (1944). Amer. F. Path. $20,239$.

Pappenheimer, A. M. \& Victor, J. (1946). Amer. F. Path. 22, 395.

Recklinghausen, F. D. von (1889). Tageblatt der 62. Versammlung deutscher Naturforscher und Aerzte, Heidelberg, p. 324 .

Ringsted, A. (1935). Biochem. F. 29, 788.

Rosenfeld, M. (1901). Arch. exp. Path. Pharmak. 45, 46.

Sheldon, J. H. (1934). Lancet, 227, 1031.

Victor, J. \& Pappenheimer, A. M. (1945). F. exp. Med. 82, 375.

Whipple, G. H. \& Robscheit-Robbins, F. S. (1925). Amer. $\mathscr{F}$. Physiol. 72, 395.

\title{
A Study of the Composition of Sow's Milk
}

\author{
BY R. BRAUDE, M. E. COATES, K. M. HENRY, S. K. KON, \\ S. J. ROWLAND, S. Y. THOMPSON AND D. M. WALKER \\ National Institute for Research in Dairying, University of Reading
}

(Received 25 April 1947)

Most of the scanty literature on the major constituents of sow's milk is old, and nothing has to our knowledge been published on its vitamin composition, with the exception of the fragmentary information about vitamins $\mathrm{A}$ and $\mathrm{C}$ mentioned below. Probably the main reason for this relative lack of information is the difficulty of obtaining satisfactory samples of sow's milk. This difficulty is stressed in every paper published on the subject, and is connected with the mechanism of the 'let down' of milk over which the sow appears to have complete control. It is well known that milk cannot be obtained from the sow by milking in the way normally effective with other large animals. Small samples of milk have been obtained mainly by subterfuge. For this purpose a piglet had to be quietly removed while the sow was suckling her litter and the vacated teat quickly milked by hand. Elly \& Petersen (194I) have lately devised a method for inducing the 'let down' of milk in the cow by the injection into her blood stream of the oxytocic principle of the pituitary. We have applied their technique to the sow with very satisfactory results, and have been able to obtain with ease from a number of sows large samples of milk at intervals throughout lactation. These samples have been analysed for major constituents and also for certain vitamins. We also obtained colostrum from the same sows in a way previously described (Braude, Kon \& Thompson, I945-6) for comparison of its composition with that of the milk. The investigation has covered the winter as well as the summer feeding of the sow, and has included a study of the effect of season and fodder on the composition of colostrum and milk. Biological tests with guinea-pigs were also done to confirm the extraordinary richness of sow's colostrum in ascorbic acid reported in our earlier paper (Braude et al. 1945-6). 
EXPERIMENTAL

Sows

Table I gives details of the sows used in this study. They were all of the Large White breed. In all, twelve lactations of nine sows were followed, six of them during the winter of $1945^{-6}$ and six in the summer of $194^{6}$.

\section{Feeding and management}

In winter the management was as already described (Braude et al. 1945-6). In summer the pigs were brought indoors for farrowing as in winter, but when the litter was I week old mother and young were transferred to pasture into movable field units

Table I. Details of sows whose colostrum and milk were examined

\begin{tabular}{|c|c|c|c|c|c|}
\hline \multirow[b]{2}{*}{ Season } & \multirow[b]{2}{*}{ Sow no. } & \multirow[b]{2}{*}{ Lactation } & \multicolumn{2}{|c|}{ Size of litter } & \multirow[b]{2}{*}{$\begin{array}{c}\text { Date of } \\
\text { farrowing }\end{array}$} \\
\hline & & & Born & $\begin{array}{l}\text { Reared at } \\
8 \text { weeks }\end{array}$ & \\
\hline \multirow[t]{6}{*}{ Winter } & I 962 & 3 & 12 & 8 & 27. xi. 45 \\
\hline & I 963 & 3 & II & 8 & Iอ. xii. 45 \\
\hline & 823 & 8 & ro & 8 & 2r. xii. 45 \\
\hline & 1836 & 4 & I 5 & 7 & 8. i. 46 \\
\hline & 1864 & 4 & II & 9 & 5. ii. 46 \\
\hline & 874 & 8 & 8 & 7 & I 8 . ii. 46 \\
\hline \multirow[t]{6}{*}{ Summer } & 860 & 8 & $2 I$ & 9 & 27. iv. 46 \\
\hline & 1962 & 4 & 13 & 9 & 3I. v. 46 \\
\hline & 201 & 3 & 13 & 10 & I3. vi. 46 \\
\hline & 823 & 9 & II & 9 & I6. vi. 46 \\
\hline & 1863 & 4 & 16 & 9 & 17. vi. 46 \\
\hline & 1836 & 5 & 19 & 7 & 9. vii. 46 \\
\hline
\end{tabular}

which were shifted every day. The pasture consisted of a 3 years' ley in its first year containing a mixture of grasses and clover. The daily shifting of the units ensured that good-quality herbage was available at all times. The sows received a balanced proprietary pig meal, $6 \mathrm{lb}$. daily in winter and $4 \mathrm{lb}$. in summer, with an additional allowance of $\frac{1}{2} \mathrm{lb}$. per piglet throughout the year. About $\mathbf{I} \%$ of veterinary cod-liver oil mixture was added to the diet of the sows while they were indoors.

\section{The collection of colostrum and milk}

Colostrum was obtained during parturition by manual expression of the udder as previously described (Braude et al. 1945-6). To obtain a sample of milk the sow was roped by placing a running noose on the upper jaw, and five units of the oxytocic principle of the pituitary $(0.5 \mathrm{ml}$. of Pitocin, Parke, Davis and Co., diluted with about ten times its volume of normal saline) were injected into the ear vein. After a few seconds, two milkers, one on each side of the sow, expressed as much milk as was possible from a number of teats into glass containers. The collected milk was transferred immediately to brown glass bottles, a sample being taken at the same time for the determination of vitamin C. As a rule $200-300 \mathrm{ml}$. of milk were collected with ease. Each sow was milked at about weekly intervals throughout the lactation period 
of 56 days. The first sample was usually taken during the first week, and the day of this first collection varied from the ist to the 7 th day. The analysis of the samples taken during the first week showed that, as would be expected, the composition in that period was changing rapidly from that of colostrum to that of later milk. In considering the composition of milk, only samples collected on and after the roth day of lactation were used, but values for the earlier samples are included in Fig. I showing lactational trends.

\section{Analytical methods}

The samples of colostrum and milk were taken to the laboratory without delay. The samples from the twelve lactations of the nine sows were analysed for total solids, fat, vitamin $A$, ascorbic acid, vitamin $B_{1}$ (free and total) and riboflavin; in addition, the samples from six of the sows, two in the winter (nos. 874 and 1836 ), and four in the summer (nos. 201, 823, 860 and 1962), season, were analysed for protein, lactose, ash, calcium and phosphorus. The fat from a pooled sample of milk was also tested on rats for vitamin $\mathrm{D}$ as described on p. 74 .

Fat was determined by the Gerber method (British Standards Institution, 1936); total solids by drying in the steam oven by the technique of Golding (1934); protein by the Kjeldahl method, the value for nitrogen being multiplied by the factor $6 \cdot 38$; lactose by the direct volumetric method of Lane \& Eynon (1923); ash by controlled incineration in an electric muffle furnace; calcium by precipitation as oxalate from a solution of the ash, and titration with permanganate; and phosphorus by precipitation as ammonium phosphomolybdate from a solution of the ash, and titration with alkali.

The methods used for determining vitamins were as previously described (Mattick, Hiscox, Crossley, Lea, Findlay, Smith, Thompson, Kon \& Egdell, 1945-6), with the exception that for vitamin $\mathrm{C}$ measurements $5 \mathrm{ml}$. of colostrum or milk were added immediately after collection to $\mathrm{I} O \mathrm{ml}$. of the precipitating mixture.

\section{RESULTS}

The results for total solids, fat, solids-not-fat and vitamins are given in Table 2. The mean values for colostrum are based on one sample from each sow, and the mean values for milk on thirty-two to thirty-eight samples in winter and on the same number in summer, all taken from the roth day of lactation onwards. The influence of the stage of lactation on the composition of the milk is shown in Fig. $x$, the data for which were obtained by straight-line interpolation from all values for all sows. The statistical significance of the lactational trends has been assessed by comparing the mean values obtained for each sow from the Ioth to the $25^{\text {th }}$ day of lactation with those obtained

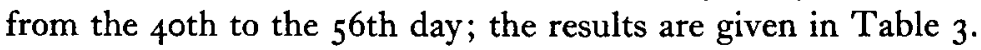

The results for protein, lactose, ash, calcium and phosphorus are given in Table 4 , along with the corresponding results for total solids, fat and solids-not-fat for the six sows concerned. The composition of each individual sample of colostrum is given, and the values for milk are mean values for the lactation of each sow from the roth day, the number of samples contributing to these values varying, as indicated, from 

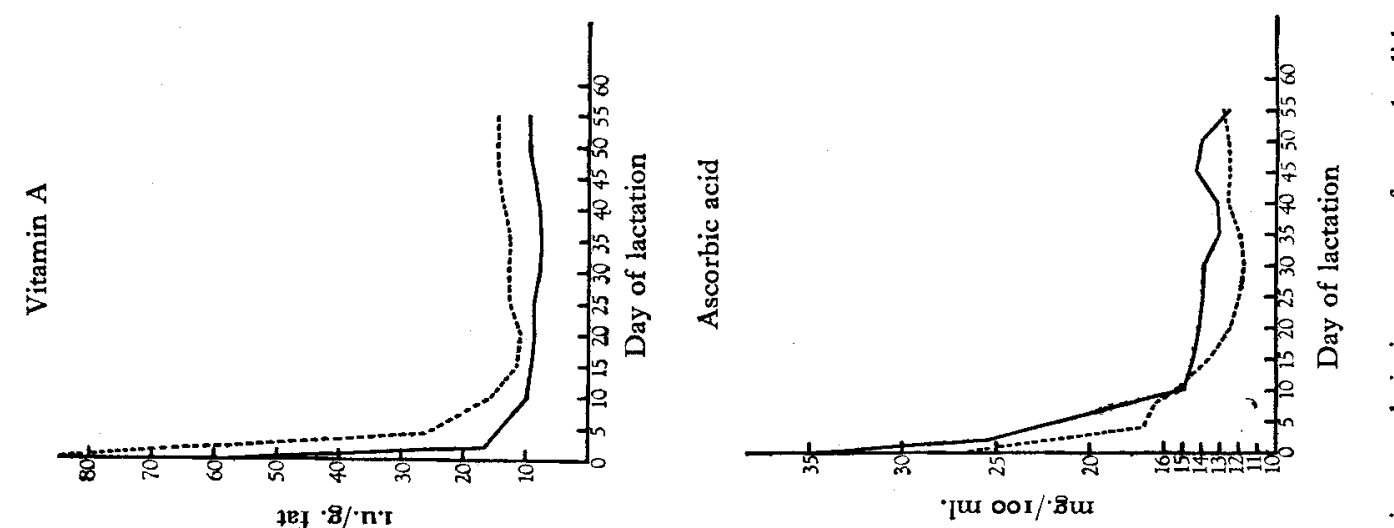

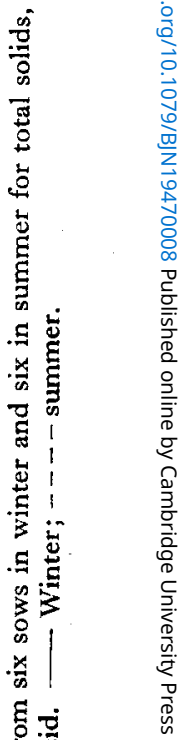
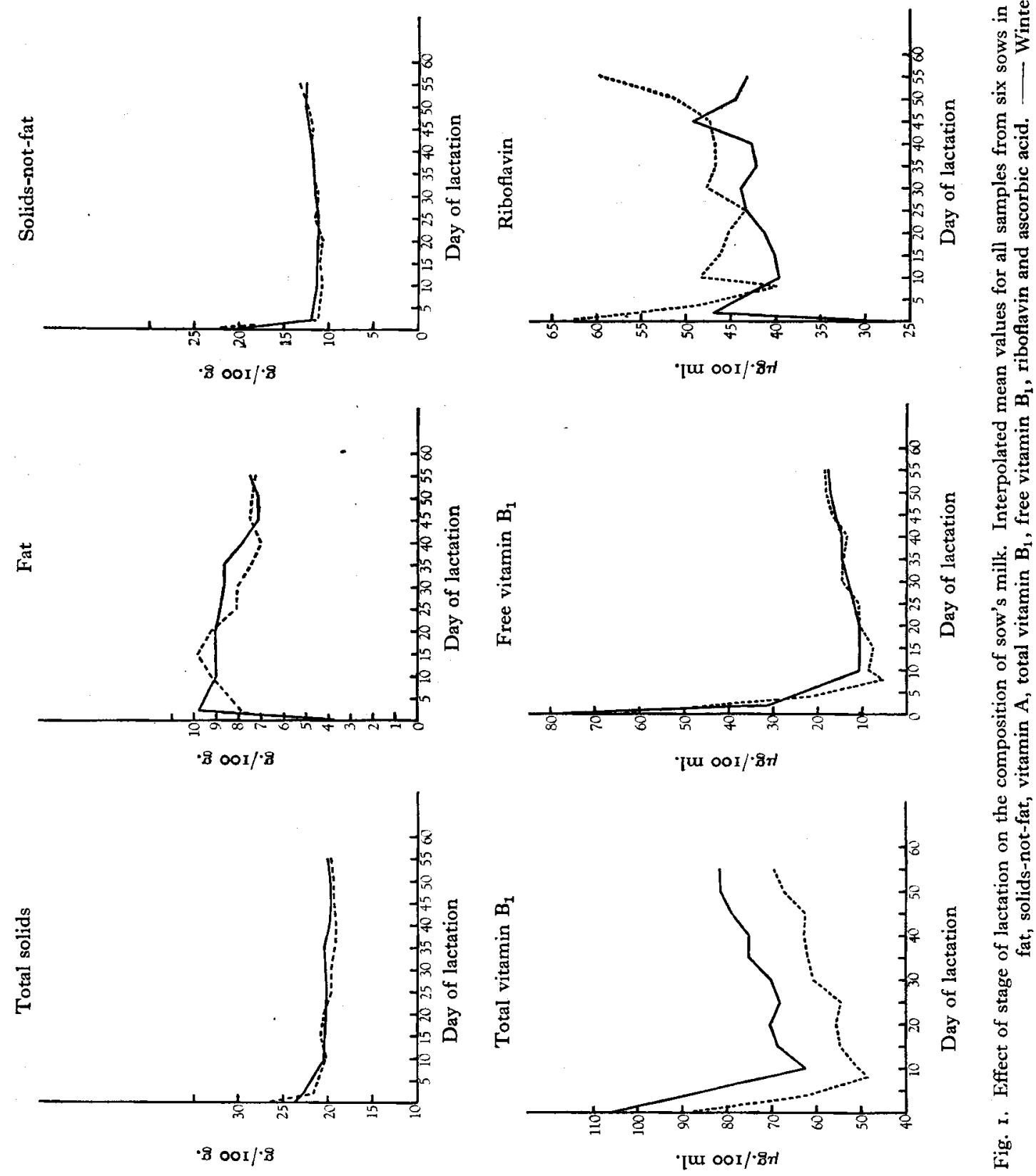
$\frac{5}{3}$

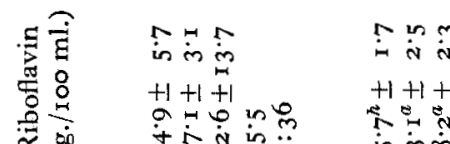

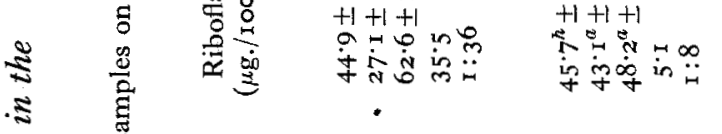

胥

롤

के

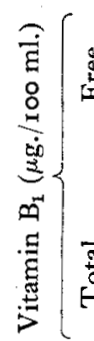

$$
\text { i }
$$

i

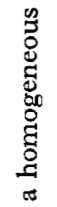

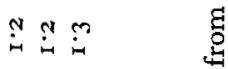

है।

ล हี่

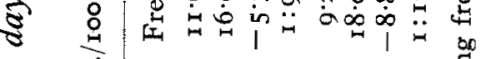

悹 完

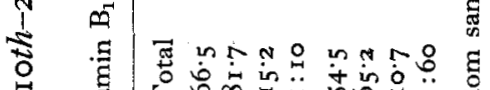

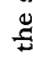

苋

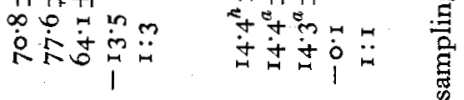

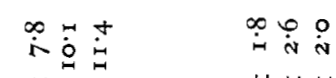

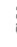

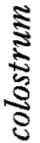

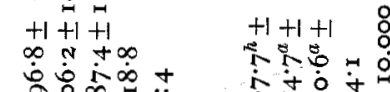

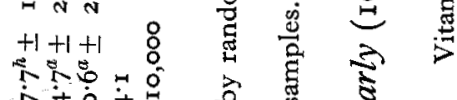

돌 $\widehat{\dot{z}}$

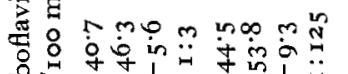

tकt

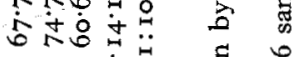

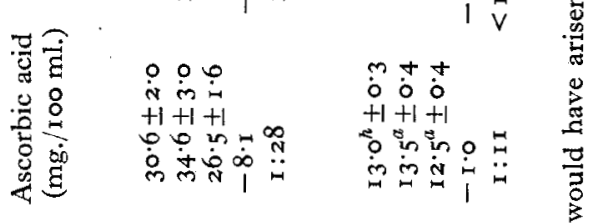

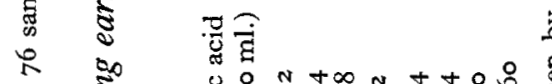

每

इ

进

ำ

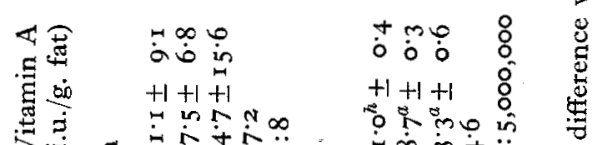

3.

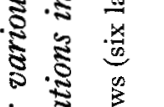

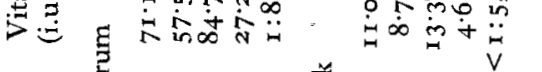

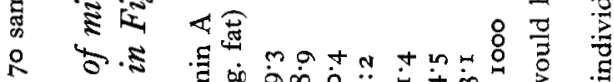

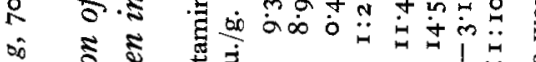

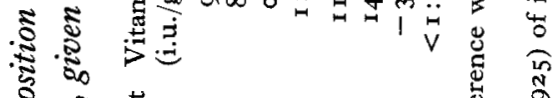

है

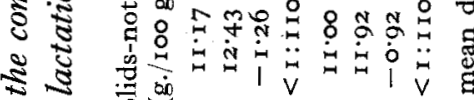

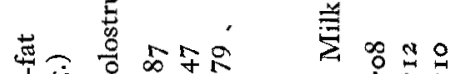

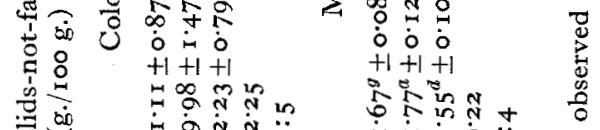

(ิ)

辛

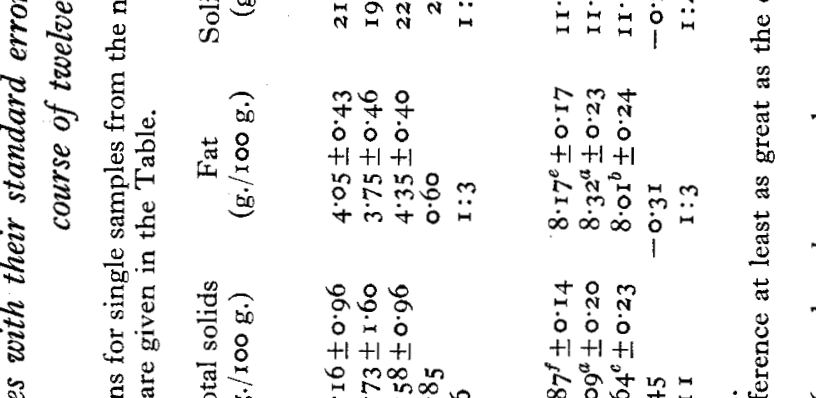

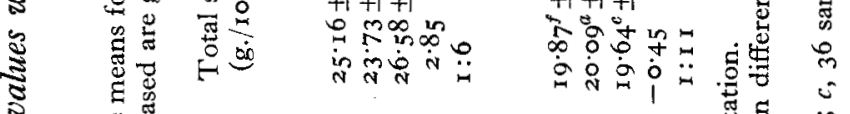

ह

¿

i $\quad: 0$

है

政

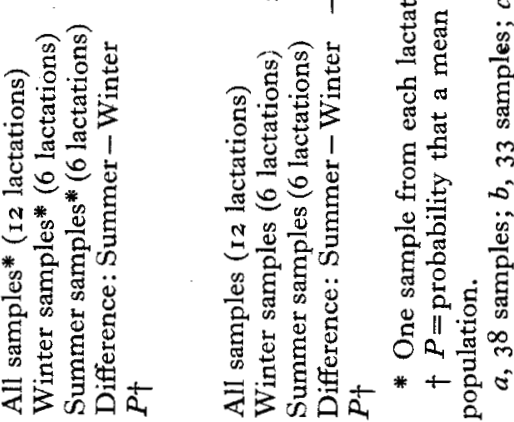

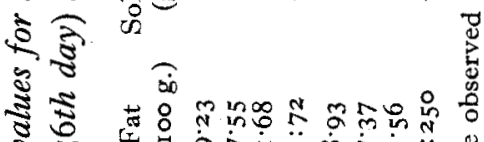

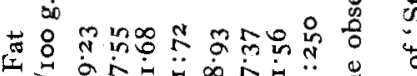

$\Rightarrow$ I

恋迹

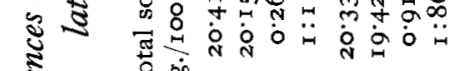

可 


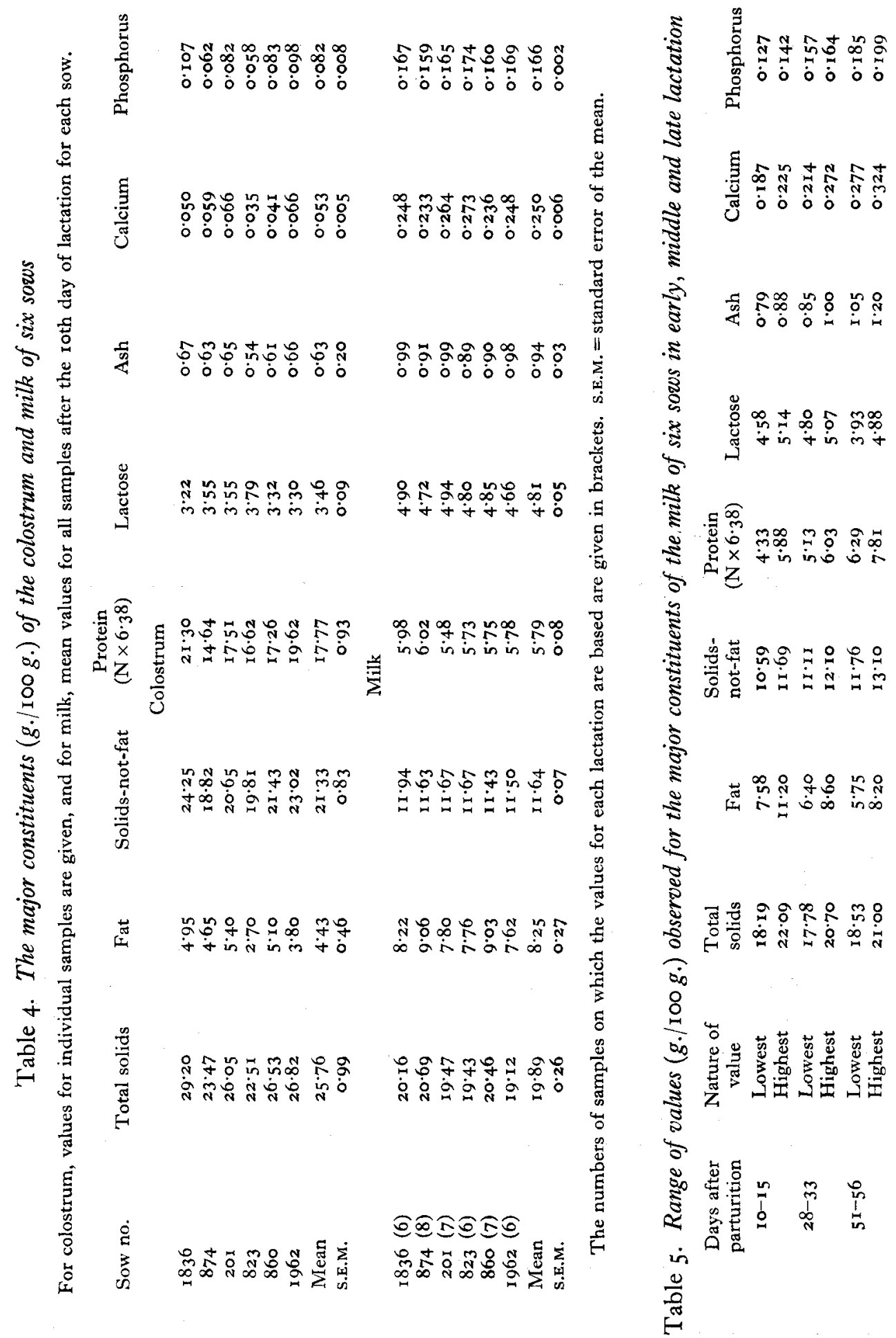


six to eight. Owing to the small number of sows involved, seasonal differences have been disregarded. The range of composition observed in the samples of milk is illustrated in Table 5 by data for early, middle and late lactation. The influence of the stage of lactation on the protein, lactose and mineral contents of the milk is shown in Fig. 2, which was obtained, like Fig. I, by straight-line interpolation from all the values for the six sows.

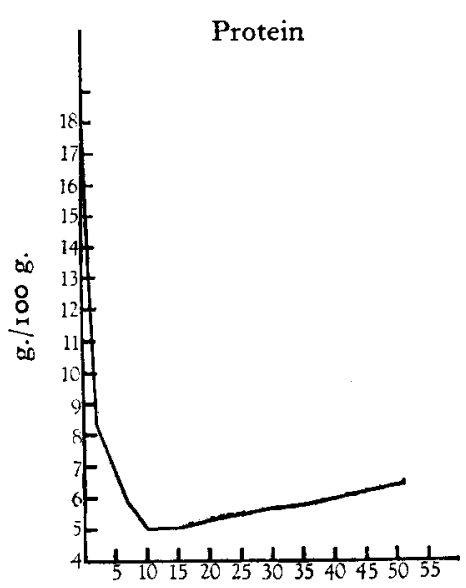

Day of lactation

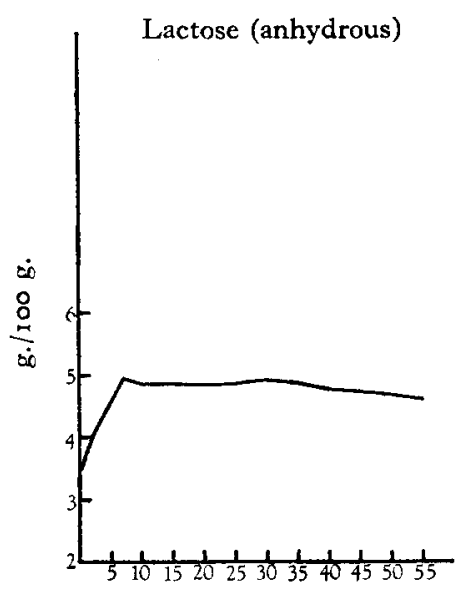

Day of lactation

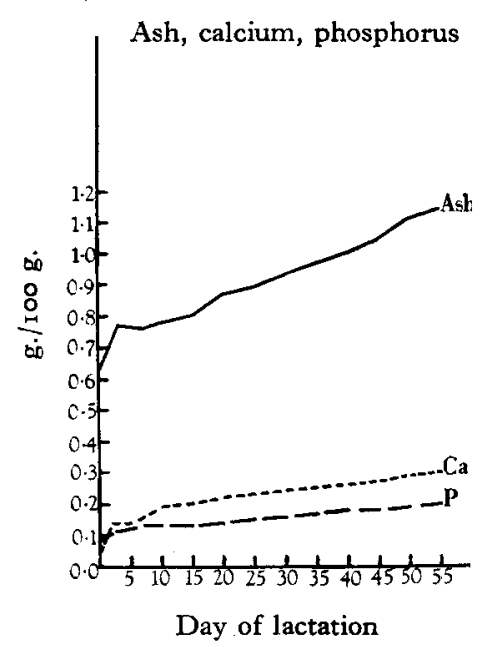

Day of lactation

Fig. 2. Effect of stage of lactation on the composition of sow's milk. Interpolated mean values for all samples from two sows in winter and four in summer for protein, lactose, ash, calcium and phosphorus.

\section{Colostrum}

\section{DISCUSSION}

Total solids, fat, and solids-not-fat

It will be seen from Table 2 that the difference between the summer and winter values is not statistically significant. The range of composition observed in the twelve samples was: total solids $17 \cdot 7-29 \cdot 4 \%$, fat $2 \cdot 0-5 \cdot 4 \%$, and solids-not-fat $14 \cdot 2-25 \cdot 0 \%$, as compared with values of $20 \cdot 6-27 \cdot 2 \%$ for total solids, $1 \cdot 7-5 \cdot 8 \%$ for fat and $17 \cdot 8$ $23.5 \%$ for solids-not-fat reported in our earlier paper (Braude et al. 1945-6). The present mean values agree with those given by Albig (I940), viz. $25.2 \%$ for total solids and $4.6 \%$ for fat. Hughes \& Hart (1935) found mean values of total solids $3 \mathrm{I} \cdot 9 \%$ and fat $5 \cdot \mathrm{x} \%$, the former a surprisingly high figure which does not appear to be consistent with the comparable mean values given by them for the separate constituents of the total solids.

\section{Milk}

The mean values do not show any significant seasonal difference in the contents of total solids, fat or solids-not-fat, but, as would be expected, the composition of the milk differs markedly from that of the colostrum, the latter containing about onequarter more total solids, double the solids-not-fat, and only one-half of the fat. 
The literature on the composition of sow's milk prior to 1935 , most of it very old, was reviewed by Hughes \& Hart (1935), who calculated the following values for the combined results of previous workers: total solids $18 \cdot 2 \%$ and fat $6.9 \%$. Hughes \& Hart themselves obtained mean values for total solids of $17.8 \%$ and for fat of $5.3 \%$. Since then Wells, Beeson \& Brody ( 1940 ) have reported values of 16.4 and $5.3 \%$, and Albig (1940) of 18.8 and $7.0 \%$. On the other hand, Newlander \& Jones (1935) reported higher values of $25.1 \%$ for total solids and I $.8 \%$ for fat.

Our mean values of 19.9 and $8.2 \%$ respectively are thus somewhat higher than those previously reported; this may perhaps be attributed to our technique for drawing the milk which permitted the collection of larger, and more nearly representative, samples than those previously obtained. We have mentioned in our earlier paper the difficulties in sampling for fat; the possibility of differences in composition arising from differences in the breed and management of the sows must also be realized.

The effect of the stage of lactation on the composition of milk is shown more clearly by the present data than by any previously recorded. As will be seen from Fig. I and Table 3, after the rapid change from colostrum to milk, the fat content decreases appreciably and the solids-not-fat content increases slightly as the lactation advances, in winter and in summer. As the result of these opposing trends the total solids content shows a very slight tendency to decrease, but significantly so only in summer.

\section{Colostrum}

\section{Protein, lactose, ash, calcium and phosphorus}

The data given in Table 4 show that the colostrum of the sow, like that of other species, has a relatively very high protein content, and it is this which accounts for the high content of solids-not-fat, in fact the concentration of lactose, ash, and particularly of calcium and phosphorus, is much lower in colostrum than in milk.

One feature of the detailed values now quoted for the composition of colostrum needs explaining, namely, the anomaly that the total of the mean lactose, protein and ash contents, all directly determined, exceeds the mean solids-not-fat content. This is probably largely due to the use of the factor $6.3^{8}$ to convert the nitrogen content into protein content, as this factor may well be too high for the actual mixture of soluble and insoluble proteins and non-protein nitrogenous constituents likely to be present in the colostrum.

\section{Milk}

Our mean values for the constituents of the solids-not-fat are in general agreement with those of previous workers; thus Hughes \& Hart (r935) found 6.34, 0.96, 0.252 and $0.151 \%$ for protein, ash, calcium and phosphorus respectively, and Wells et al. (1940) $4.86,0.92,0.216$ and $0.125 \%$ respectively. Values for lactose by direct determination were not previously reported.

The influence of the stage of lactation on these constituents is clearly shown in Fig. 2. After the end of the colostral period the protein, ash, calcium and phosphorus contents steadily rise, and that of lactose slowly falls.

A comparison of the composition of the milk of the sow with that of other farm animals shows that it contains a higher percentage of total solids, fat, solids-not-fat, 
protein, ash, calcium and phosphorus than the milk of the cow and goat, and about the same percentage of lactose. With regard to all these major constituents sow's milk very closely resembles ewe's milk, the data on the composition of which were reviewed by Godden \& Puddy (1935).

\section{Colostrum}

\section{Vitamins}

The mean values given in Table 2 agree on the whole with those quoted in our previous paper (Braude et al. 1945-6) with the exception of those for vitamin $B_{1}$, the present value being significantly lower than the earlier. We have no obvious explanation to offer; one might speculate on differences in vitamin $B_{1}$ content of the proprietary meal mixture which the sows received, but we have no information on this point.

It is known (Houston, Kon \& Thompson, 1940) that in cow's milk vitamin $B_{1}$ occurs in a 'free' form and also bound, much of it phosphorylated. It was of interest to find out the form in which the vitamin was present in sow's colostrum and milk, and for this purpose measurements were made before and after treatment with takaphosphatase. The larger part of the vitamin $B_{1}$ of colostrum was found present in the free form. It will be recalled that the colostrum was collected during parturition, and it is of interest that Houston et al. (1940) found a similar ratio in the first colostrum of the cow. The relation between the titre of alkaline phosphomono-esterase and the free and bound vitamin $B_{1}$ will be discussed later.

Of the seasonal differences the only significant ones are in riboflavin and ascorbic acid. The higher riboflavin content in summer might well be connected with the generous supply of fresh herbage. No obvious reason can be advanced for the lower vitamin $\mathrm{C}$ content of the summer colostrum.

Biological assay of vitamin $C$ in colostrum. We have already commented (Braude et al. I $945^{-6)}$ on the relatively high concentration of vitamin $C$ in sow's colostrum. The substance proved more labile on standing at room temperature than vitamin $\mathrm{C}$ in cow's milk, but it was little affected by exposure to light. This is perhaps not surprising in view of the very low ratio in sow's colostrum of riboflavin to vitamin C. In fact, colostrum to which riboflavin was added at the rate of $200 \mu \mathrm{g}$. $/ 100 \mathrm{ml}$. lost its vitamin C in the characteristic way on exposure to light. These preliminary chemical tests indicated that, in all probability, the substance measured by the indophenol titration was in fact ascorbic acid. We felt, however, that values so unusually high required confirmation by biological proof. For this purpose sufficient colostrum for a biological test was collected and distributed into small nickel dishes, so that each dish contained enough for I day's dosing. The colostrum was then immediately frozen at $-30^{\circ}$ and maintained at a temperature of at least $-25^{\circ}$ in an atmosphere of $\mathrm{CO}_{2}$ until needed. Chemical determinations made at the beginning and end of the assay showed no loss of ascorbic acid during the period of storage.

The method used for the biological test was essentially similar to the curative growth method described by Harris \& Olliver (1942). The scorbutogenic diet, offered ad libitum, consisted of 45 parts of bran, 25 parts of oats, and $3^{\circ}$ parts of dried skim 
milk with individual supplements of 1000 i.u. vitamin A and 100 B.S.I. units (British Standards Institution, I940) of vitamin $\mathrm{D}_{3}$ twice weekly. The skim milk had previously been tested for freedom from ascorbic acid.

Newly weaned guinea-pigs were given a stock diet of bran, oats and fresh greenstuff until they reached a body weight of $280-300 \mathrm{~g}$. They were then transferred to the scorbutogenic diet and weighed daily. They continued to grow for some days, then began to lose weight. As soon as a steady fall in weight was observed, usually about the 12 th to the 16 th day, they were assigned to receive standard ascorbic acid solutions or colostrum.

Three dose levels were used for each substance, equivalent to $1 \cdot 0,0.5$ and $0.25 \mathrm{mg}$. of ascorbic acid daily, with five or six animals on each. Doses were given daily for I 3 days, and the results were assessed on the difference in weight of the animals at the beginning and the end of the dosing period. They were interpreted by the common slope method, as described in the B.S.I. pamphlet no. 9 II (British Standards Institution, 1940) for the assay of vitamin $\mathrm{D}_{3}$. The lines of response to the standard and test material were straight and parallel, and the calculated potency was $27.4 \mathrm{mg}$. ascorbic acid/100 ml. colostrum, with limits of error at $P=0.95$ of $2 \mathrm{I} .8$ and $34.3 \mathrm{mg}$./ $100 \mathrm{ml}$. The result by chemical determination was $26.4 \mathrm{mg}$. $/ 100 \mathrm{ml}$.

Another test was made on a different sample of colostrum by a modification of the serum phosphatase method suggested by Gould \& Schwachman (1943). The same scorbutogenic diet was used and the animals were treated as in the previous test until the day when dosing was due to begin. Blood was withdrawn by heart puncture, and the serum alkaline phosphatase was determined by the method of King \& Armstrong (1934). Daily dosing was then begun at levels of 0.3 and $0.6 \mathrm{mg}$. ascorbic acid and continued for 12 days, when a further sample of blood was taken and the phosphatase again measured. The change in phosphatase, in King \& Armstrong units, was used to calculate the potency by the method of Irwin (1937) and gave a value of $22.8 \mathrm{mg}$. ascorbic acid/100 ml. colostrum. The result by chemical determination was $30.0 \mathrm{mg}$./ $100 \mathrm{ml}$. As only eight animals were used for the whole test the result can only be regarded as tentative and no reasonable limits of error can be stated, but once again the value calculated was close to that obtained chemically. This technique is suggested as a practical and possibly more specific alternative to the growth method.

\section{Milk}

Vitamin A. The mean vitamin A content of the milk fat was much lower than that of colostral fat, Ir.O against $7 \mathrm{I} \cdot \mathrm{I}$ i.u./g., that is, barely one-sixth. When, however, the amounts of vitamin A in colostrum and milk are compared, the difference is less marked because of the higher fat content of milk.

The winter value, 8.7 i.u./g., was significantly lower than the summer value, 1 3.3 i.u./g. This is of interest, as in winter the sows received cod-liver oil mixture throughout lactation, whereas in summer they did not. The cod-liver oil given at the rate of $1 \%$ of the diet supplied about 40,000 i.u. of vitamin $\mathrm{A} /$ week, if its potency is taken as $1000 \mathrm{i} . u$./g. Presumably the generous intake of carotene from herbage supplied more vitamin $A$ in summer than was derived in winter from the cod-liver oil. 
Fig. $\mathrm{I}$ indicates, in summer, a slight but steady increase in the concentration of the vitamin $A$ in milk fat with progressing lactation, and Table 2 shows that this is significant. It will be recalled that the fat content of the milk showed at the same time a similarly significant but opposite trend. The concentration of vitamin A in the milk remained therefore approximately constant. No trend was apparent in the concentration of vitamin $A$ in the milk fat in winter. As the fat content decreased with the progress of lactation the total amount of vitamin A in milk gradually declined. These findings may suggest that the amount of vitamin A which the sows received in winter was not sufficient to maintain a steady output of it in the milk.

Information about the vitamin A content of sow's milk is very scanty. We are only aware of a publication by Schofield, Ingle \& McFarlane (1942), which we are unable to interpret with certainty as the authors do not state the volume of milk to which their figures refer. If it is assumed that the figures are for $100 \mathrm{ml}$. they would be of the same order as our data.

The concentration of vitamin A in the fat of sow's milk is less than that found in the milk of the cow, which in this country amounts to about 10-20 i.u./g. in early spring, but on pasture may rise to about 30-40 i.u./g. (Kon, 1945). These values refer to the total vitamin A activity, as cow's milk contains both preformed vitamin A and carotene. When milk itself is considered the difference is much less marked, as sow's milk contains about twice as much fat as that of the cow.

Barron's (1942) data for the vitamin A content of ewe's milk in this country, recalculated in the way given in our earlier paper (Braude et al. 1945-6), are of the order of 2 i.u./g. fat. The mean value of 20 i.u./100 ml. given by Underwood \& Curnow (1944) for ewe's milk at the same stage of lactation is of about the same order. These values are distinctly lower than our values for sow's milk. It should, however, be noted that Underwood \& Curnow (1944) observed a considerable increase in the vitamin A potency of the milk of their ewes after they had had access to young pasture and oat silage.

Vitamin D. Between July and December 1946 the surplus milk from all collections from all sows was pooled, and the separated fat was tested on rats for its vitamin D content by the prophylactic bone-ash method (Kon \& Henry, 1935). The tests were done on groups of twelve rats in litter-mate comparisons, and levels of 0.2 and $0.4 \mathrm{~g}$. of fat daily were assayed against $0.05,0.1$ and 0.2 i.u. levels of the international standard for vitamin D. The results were calculated by the British Standards Institution (1940) method, giving for fat a potency of 0.55 i.u./g. with true fiducial limits at $P=0.95$ of 0.43 and 0.75 . This value is within the range observed in this country for the vitamin D content of cow's milk fat (Henry \& Kon, 1942).

Vitamin $B_{1}$. The total vitamin $B_{1}$ content of milk is lower, but not markedly so, than that of colostrum. On the other hand, the difference between the concentration of the free form is striking (Table 2). The total vitamin $B_{1}$ content of winter milk is significantly higher than that found in summer, but there is no difference in the free form. The reason for the seasonal change is not clear.

Fig. $x$ shows that vitamin $B_{1}$ increases with the progress of lactation. In summer the trend was significant, in winter suggestive but not significant. 
The vitamin $B_{1}$ content of sow's milk is decidedly higher than that of cow's milk (Houston et al. I940) and of goat's milk (Holmes, Lindquist, Jones, Wertz, Esselen, McKey \& Fuller, r945), but about the same as in that of the ewe (Pearson \& Darnell, I946).

In Table 6 are listed measurements of the alkaline phosphomono-esterase in samples of colostrum and milk and also the corresponding values for free and total vitamin $B_{1}$. It is clear that, as with the milk of the cow and of the goat (Houston et al.

Table 6. The phosphomono-esterase content and the free and total vitamin $B_{1}$ of sow's colostrum and milk

\begin{tabular}{|c|c|c|c|c|}
\hline \multirow[b]{2}{*}{ Sow no. } & \multirow[b]{2}{*}{ Days in lactation } & \multirow{2}{*}{$\begin{array}{l}\text { Phosphomono- } \\
\text { esterase in } \\
\text { King \& } \\
\text { Armstrong } \\
\text { (1934) units }\end{array}$} & \multicolumn{2}{|c|}{ Vitamin $\mathrm{B}_{1}(\mu \mathrm{g} \cdot / 100 \mathrm{ml})}$. \\
\hline & & & Free & Total \\
\hline \multirow[t]{5}{*}{874} & $\begin{array}{c}\text { At farrowing } \\
\text { I0 } \\
\text { I5 }\end{array}$ & $\begin{array}{r}43 \cdot 7 \\
5 \cdot 4 \\
2 \cdot 8\end{array}$ & $\begin{array}{r}100 \cdot 0 \\
15.6 \\
16 \cdot 2\end{array}$ & $\begin{array}{r}147 \cdot 0 \\
8 I \cdot I \\
85 \cdot 5\end{array}$ \\
\hline & 22 & $7 \cdot 7$ & $19 \cdot 5$ & $77 \cdot 5$ \\
\hline & 29 & $3 \cdot 8$ & $12 \cdot 3$ & $63 \cdot 3$ \\
\hline & $3^{6}$ & $5 \cdot 7$ & 13.9 & $97^{\circ} \mathrm{I}$ \\
\hline & $\begin{array}{l}43 \\
50\end{array}$ & $\begin{array}{l}7 \cdot 3 \\
8 \cdot 8\end{array}$ & $\begin{array}{l}19.5 \\
20.7\end{array}$ & $\begin{array}{l}95.9 \\
87.5\end{array}$ \\
\hline \multirow[t]{5}{*}{1836} & $\begin{array}{l}\text { At farrowing } \\
\qquad \mathbf{2 1}\end{array}$ & $\begin{array}{r}43 \cdot 5 \\
6.9\end{array}$ & $\begin{array}{r}103.0 \\
10.6\end{array}$ & $\begin{array}{r}110.0 \\
90.0\end{array}$ \\
\hline & 28 & $6 \cdot 2$ & $9 \cdot 5$ & $94^{\circ} \circ$ \\
\hline & 38 & $7 \cdot 3$ & $10 \cdot 0$ & $90 \cdot 4$ \\
\hline & 42 & $5 \cdot 3$ & $7 \cdot 8$ & $92 \cdot 0$ \\
\hline & 51 & $12 \cdot 3$ & $9 \cdot 7$ & $80 \cdot 0$ \\
\hline \multirow[t]{5}{*}{1963} & At farrowing & - & $43 \cdot 0$ & $83 \cdot 0$ \\
\hline & 2 & $26 \cdot 8$ & $24 \cdot 6$ & $89 \cdot 0$ \\
\hline & 30 & $9 \cdot 5$ & $I \cdot 2$ & $60 \cdot 0$ \\
\hline & 48 & 47 & 19.5 & 87.0 \\
\hline & 55 & II'I & $12 \cdot 2$ & $8 I \cdot 0$ \\
\hline \multirow[t]{6}{*}{823} & At farrowing & - & $86 \cdot 0$ & $95 \cdot 0$ \\
\hline & I 2 & $25^{-6}$ & I9.5 & 49.0 \\
\hline & 21 & I $8 \cdot 0$ & $8 \cdot 4$ & $65 \cdot 0$ \\
\hline & 39 & I $8 \cdot I$ & $25^{\circ} 6$ & $73^{\circ} 0$ \\
\hline & 46 & II·3 & $34^{\circ} \circ$ & $94 \cdot 0$ \\
\hline & 56 & $18: 4$ & 29.5 & 104.0 \\
\hline
\end{tabular}

I940), the lower the enzyme titre, the higher the content of the bound, presumably phosphorylated, form of vitamin $B_{1}$. The concentration of vitamin $B_{1}$ in sow's milk, the relatively low content of the free form, and also the low phosphatase titre are very much as in goat's milk. Cow's milk contains less of the total, and a higher proportion of the free, vitamin $B_{1}$ and its phosphatase titre is also very much higher.

Riboflavin. The riboflavin content of milk is about the same as of colostrum. This is of interest because of the marked difference in this respect between the colostrum and later milk of the cow. The slight difference indicated by the mean figure in favour of summer milk as compared with winter is not statistically significant. There is, however, a seasonal difference in lactational trend, the rise shown in Fig. I being significant in summer but fortuitous in winter. 
In comparison with that of other farm animals, sow's milk is low in riboflavin. Thus our mean value for all samples of $46 \mu \mathrm{g}$./100 ml. is only one-third of that for the riboflavin content of the milk of the cow (Houston et al. 1940) and of the goat (Holmes et al. 1945), and only one-tenth of that of the ewe (Pearson \& Darnell, 1946). This low level of riboflavin in the milk of an animal whose young grow at a very rapid rate, doubling their birth weight in about $\mathrm{I}_{4}$ days, is puzzling. It indicates that the relationship between the concentration of certain essential nutrients in the milk and the growth rate of the young suggested by Pearson \& Darnell ( (1946) does not always hold good.

Ascorbic acid. The vitamin C content of sow's milk is lower than that of colostrum, I $3.0 \mathrm{mg}$. as compared with $30.6 \mathrm{mg}$. $/ 100 \mathrm{ml}$. There was no seasonal difference and also little indication of a lactational trend, though the slight increase observed in later lactation in summer was statistically significant.

We have been able to find in the literature only one reference to the ascorbic acid content of sow's milk, that of Nordfeld (1944-5). He found for one normal sow a value of $6 \cdot \mathrm{I} \mathrm{mg}$. ascorbic acid/100 ml. of milk, and for a sow receiving a vitamin A-deficient diet $4.1 \mathrm{mg}$./ $/ \mathrm{roO} \mathrm{ml}$.

Sow's milk is much richer in ascorbic acid than that of the cow, which contains between 2 and $2.5 \mathrm{mg}$./100 ml. (Kon \& Watson, 1937), that of the goat, with $0.5-$ $2.0 \mathrm{mg}$. $1100 \mathrm{ml}$. (Richmond, Satterfield, Grinnells \& Dann, 1940), and that of the ewe, which, according to Satterfield, Bewley, Foster \& Hostetler (I942), contains only $0.8 \mathrm{mg} . / 100 \mathrm{ml}$. The reason for this peculiarly high concentration of ascorbic acid in sow's milk is obscure to us, and we are at present studying this problem in more detail.

\section{SUMMARY}

I. The composition has been studied of the colostrum and milk of nine Large White sows in the course of twelve lactations, six in summer and six in winter. The colostrum was obtained by manual expression during parturition, and the milk at weekly intervals during lactation also by manual expression after intravenous injection of the oxytocic principle of the pituitary.

2. The mean values for twelve samples of colostrum were: total solids $25 \cdot 16 \pm 0.96 \mathrm{~g}$. $/ 100 \mathrm{~g}$; ; fat $4.05 \pm 0.43 \mathrm{~g} . / 100 \mathrm{~g}$; ; solids-not-fat $2 \mathrm{I} \cdot \mathrm{II} \pm 0.87 \mathrm{~g}$./100 g.; vitamin $A 7_{7} \cdot I \pm 9^{\cdot} \cdot \mathrm{I}$ i.u. $/ \mathrm{g}$. fat; ascorbic acid $30 \cdot 6 \pm 2 \cdot 0 \mathrm{mg} . / \mathrm{I} 00 \mathrm{ml}$; total vitamin $B_{1}$ $96 \cdot 8 \pm 7.8 \mu \mathrm{g} . / 100 \mathrm{ml}$; free vitamin $B_{1} 70 \cdot 8 \pm 7.8 \mu \mathrm{g} . / 100 \mathrm{ml}$.; riboflavin $44.9 \pm 5.7 \mu \mathrm{g} . / 100 \mathrm{ml}$. The ascorbic acid value was significantly lower, and that for riboflavin significantly higher, in summer than in winter. Biological tests with guineapigs confirmed the high value for ascorbic acid found by indophenol titration.

3. The mean values for the milk, based on the analysis of from seventy to seventysix samples from the roth to 56 th day of lactation, were: total solids $19.87 \pm 0.14 \mathrm{~g}$. I00 g.; fat $8.17 \pm 0.17 \mathrm{~g} . / 100 \mathrm{~g}$; solids-not-fat Ir. $67 \pm 0.08 \mathrm{~g} . / \mathrm{I00}$ g.; vitamin A II.0 \pm 0.4 i.u./g. fat; ascorbic acid $13.0 \pm 0.3 \mathrm{mg} . / 100 \mathrm{ml}$; total vitamin $\mathrm{B}_{1} 67.7$ $\pm \mathrm{I} \cdot 8 \mu \mathrm{g}$. $/ \mathrm{r} 00 \mathrm{ml}$; ; free vitamin $\mathrm{B}_{1} \mathrm{I} 4 \cdot 4 \pm \mathrm{r} \cdot 2 \mu \mathrm{g}$ / $/ \mathrm{r} 00 \mathrm{ml}$; riboflavin $45 \cdot 7 \pm \mathrm{I} \cdot 7 \mu \mathrm{g}$./ I00 $\mathrm{ml}$. The vitamin A value was significantly higher, and that for total vitamin $\mathrm{B}_{\mathbf{1}}$ significantly lower, in summer than in winter. 
4. Measurements of the alkaline phosphomono-esterase in samples of colostrum and milk showed that the lower the enzyme titre, the higher the content of the bound, presumably phosphorylated, form of vitamin $B_{1}$,

5. The vitamin D content of a pooled sample of the milk fat, measured biologically, was 0.55 i.u./g. fat.

6. The milk samples from six of the sows were further analysed for major constituents, the following values (g./ I0o g.) being obtained. (I) Colostrum: protein $17.77 \pm 0.93$; lactose $3.46 \pm 0.09$; ash $0.63 \pm 0.20$; calcium $0.053 \pm 0.005 ;$ phosphorus $0.082 \pm 0.008$. (2) Milk: protein $5.79 \pm 0.08$; lactose $4.8 \mathrm{I} \pm 0.05$; ash $0.94 \pm 0.03$; calcium $0.250 \pm 0.006$; phosphorus $0.166 \pm 0.002$.

7. The changes in the composition of the milk with the stage of lactation were studied and their significance assessed.

8. Comparison of the composition of the milk of the sow with that of the cow, goat and ewe showed that, in general, sow's milk was most similar to ewe's milk, with the exception that it had a higher ascorbic acid and lower riboflavin content.

We are greatly indebted to Mr J. E. C. Mullen for the phosphatase measurements, to Miss E. E. Shepheard for help in the vitamin C tests and to Mr A. Wagstaff and Miss E. Martin for help with the determination of the major constituents.

\section{REFERENCES}

Albig, A. (1940). Tierernährung, I2, 131.

Barron, N. S. (1942). Vet. Rec. 54, 29.

Braude, R., Kon, S. K. \& Thompson, S. Y. (1945-6). F. Dairy Res. 14, 4 14.

British Standards Institution (1936). Specification, no. 696, part 2, p. 9.

British Standards Institution (1940). Specification, no. 9I I.

Elly, F. \& Petersen, W. E. (r94r). F. Dairy Sci. 24, 2 I 1.

Godden, W. \& Puddy, C. A. (1935). F. Dairy Res. 6, 307.

Golding, J. (1934). Analyst, 59, 468.

Gould, B. S. \& Schwachman, H. (1943). F. biol. Chem. I5I, 439.

Harris, L. J. \& Olliver, M. (1942). Biochem. $\mathcal{F} .3^{6}$, I 55 .

Henry, K. M. \& Kon, S. K. (1942). Biochem. F. 36, 456.

Holmes, A. D., Lindquist, H. G., Jones, C. P., Wertz, A. W., Esselen, K., McKey, M. S. \& Fuller, E. (1945). New Engl. F. Med. 232, 72.

Houston, J., Kon, S. K. \& Thompson, S. Y. (I940). F. Dairy Res. rr, I45.

Hughes, E. H. \& Hart, H. G. (1935). F. Nutrit. 9, 311.

Irwin, J. O. (1937). F. R. statist. Soc. Suppl. 4, I.

King, E. J. \& Armstrong, A. R. (1934). Canad. med. Ass. F. 31, 376.

Kon, S. K. (1945). F. R. Soc. Arts, 93, 122.

Kon, S. K. \& Henry, K. M. (1935). Biochem. F. 29, 205 I.

Kon, S. K. \& Watson, M. B. (1937). Biochem. F. 31, 223.

Lane, J. H. \& Eynon, L. (1923). F. Soc. chem. Ind., Lond., 42, 32 T.

Mattick, A. T. R., Hiscox, E. R., Crossley, E. L., Lea, C. H., Findlay, G. D., Smith, J. A. B., Thompson, S. Y., Kon, S. K. \& Egdell, J. W. (1945-6). F. Dairy Res. r4, II6.

Newlander, J. A. \& Jones, C. H. (1935). Bull. Vt agric. Exp. Sta. no. 389.

Nordfeld, S. (1944-5). Ann. agric. Coll., Sweden, 12, 204.

Pearson, P. B. \& Darnell, A. L. (1946). F. Nutrit. 3r, 5 r.

Richmond, M. S., Satterfield, G. H., Grinnells, C. D. \& Dann, W. J. (1940). J. Nutrit. $20,99$.

Satterfield, G. H., Bewley, E. A. Jr., Foster, J. E. \& Hostetler, E. H. (1942). F. Nutrit. 24 , I 21.

Schofield, F. W., Ingle, R. T. \& McFarlane, W. D. (1942). Rep. Ont. vet. Coll. 1941, p. I6.

'Student' (1908). Biometrika, 6, I.

'Student' (1925). Metron, 5, 105.

Underwood, E. J. \& Curnow, D. H. (1944). Aust. vet. F. 20, 282.

Wells, W., Beeson, W. M. \& Brody, D. E. (1940). Bull. Idaho agric. Exp. Sta. no. 236, p. 9. 